\title{
Gastrointestinal nematodes of European roe deer (Capreolus capreolus) in Russia
}

\author{
Dmitry N. Kuznetsov*, Natalya B. Romashova \& Boris V. Romashov
}

ABSTRACT. The species composition of gastrointestinal nematodes parasitizing European roe deer Capreolus capreolus in Russia was studied. Fourteen individuals of $C$. capreolus from three regions of European Russia (Ryazan', Tver' and Voronezh) were examined at necropsy in the period of 2013-2019 for the nematode infections. Beside this, the species identification of nematodes collected from four individuals of C. capreolus in Voronezh State Nature Reserve in 1980s was performed. Fifteen species of nematodes were detected: Ashworthius sidemi, Bunostomum trigonocephalum, Chabertia ovina, Mazamastrongylus dagestanica, Nematodirus filicollis, Ostertagia antipini (including minor morph "Ostertagia lyrataeformis"), Ostertagia leptospicularis, Ostertagia ostertagi, Spiculopteragia asymmetrica (including minor morph "Spiculopteragia quadrispiculata"), Spiculopteragia spiculoptera, Teladorsagia circumcincta, Trichostrongylus axei, Trichostrongylus colubriformis, Trichostrongylus vitrinus and Trichuris globulosa. The biggest variety of nematodes (12 species) has been noted in abomasa. Four species (N. filicollis, T. axei, T. colubriformis and T. vitrinus) were detected both in abomasa and small intestines, but the first one prevailed in small intestines whereas Trichostrongylus spp. - in abomasa. This is the first detection of S. asymmetrica (as well as its minor morph "S. quadrispiculata") in European roe deer in Russia. Asian nematode A. sidemi was found in two regions (Tver' and Voronezh) in majority of roe deer individuals studied in 2013-2019, but was not found in the samples collected in 1980s, that confirms the trend for spreading of this parasite, noted in Europe last years.

How to cite this article: Kuznetsov D.N., Romashova N.B., Romashov B.V. 2020. Gastrointestinal nematodes of European roe deer (Capreolus capreolus) in Russia // Russian J. Theriol. Vol.19. No.1. P.85-93. doi: 10.15298/rusjtheriol.19.1.09.

KEY WORDS: wild ruminants, Capreolus capreolus, digestive tract, parasitic nematodes, European Russia, Ashworthius sidemi, Spiculopteragia asymmetrica.

Dmitry N. Kuznetsov [dkuznetsov@mail.ru], Center of Parasitology of A.N. Severtsov Institute of Ecology and Evolution RAS, Mytnaya str. 28 / 1, Moscow 119049, Russia; All-Russian Scientific Research Institute of Fundamental and Applied Parasitology of Animals and Plants - a branch of the Federal State Budget Scientific Institution "Federal Scientific Centre VIEV”, Bolshaya Cheremushkinskaya str. 28, Moscow 117218, Russia; Natalya B. Romashova [bvnrom@rambler.ru], Voronezh State Nature Biosphere Reserve, Voronezh 394080, Russia; Boris V.Romashov [bvrom@rambler.ru], Voronezh State Agricultural University, Mitchurina str. 1, Voronezh 394087, Russia; Voronezh State Nature Biosphere Reserve, Voronezh 394080, Russia.

\section{Нематоды желудочно-кишечного тракта европейской косули (Capreolus capreolus) в России}

\author{
Д.Н. Кузнецов ${ }^{*}$ Н.Б. Ромашова, Б.В. Ромашов
}

РЕЗЮМЕ. Определен видовой состав нематод желудочно-кишечного тракта, обнаруженных у европейской косули Capreolus capreolus в России. Нематоды были собраны в 2013-2019 гг. при вскрытиях 14 косуль из Рязанской, Тверской и Воронежской областей. Кроме того, определен видовой состав нематод от четырех косуль из сборов 1980-х гг., хранившихся в Воронежском государственном заповеднике. Обнаружены нематоды 15 видов: Ashworthius sidemi, Bunostomum trigonocephalum, Chabertia ovina, Mazamastrongylus dagestanica, Nematodirus filicollis, Ostertagia antipini (в том числе и минорная морфа этого вида — “Ostertagia lyrataeformis"), Ostertagia leptospicularis, Ostertagia ostertagi, Spiculopteragia asymmetrica (в том числе, минорная морфа — “Spiculopteragia quadrispiculata”), Spiculopteragia spiculoptera, Teladorsagia circumcincta, Trichostrongylus axei, Trichostrongylus colubriformis, Trichostrongylus vitrinus и Trichuris globulosa. Наибольшее количество видов нематод (12 видов) отмечено в сычуге. Четыре вида (N. filicollis, T. axei, T. colubriformis и T. vitrinus) были обнаружены как в сычуге, так и в тонком кишечнике, однако первый вид превалировал в тонком ки-

\footnotetext{
* Corresponding author
} 
шечнике, a Trichostrongylus spp. - в сычуге. Впервые у европейской косули в России зарегистрирована нематода $S$. asymmetrica (а также минорная морфа этого вида — “S. quadrispiculata”). Азиатская нематода A. sidemi обнаружена в двух областях (Тверской и Воронежской) у большинства косуль, исследованных в 2013-2019 гг, однако не была обнаружена в сборах 1980-х гг. Это подтверждает тенденцию к распространению этого паразита, отмеченную в последнее время в Европе.

КЛЮЧЕВЫЕ СЛОВА: дикие жвачные, Capreolus capreolus, пищеварительный тракт, паразитические нематоды, Европейская Россия, Ashworthius sidemi, Spiculopteragia asymmetrica.

\section{Intrtoduction}

European roe deer (Capreolus capreolus Linnaeus, 1758 ) is one of the most abundant species among wild ruminants in Europe (Grubb, 2005). Russia has a good potential for increasing of population of C. capreolus, but currently the population is relatively small and has about 92 thousand individuals (Danilkin, 2014). Helminth infection deteriorates the health conditions of wild ruminants (Stien et al., 2002; Irvin et al., 2006; Osinska et al., 2010) and occupies a significant place among the causes of mortality in roe deer (Aguirre et al., 1999). Data on the taxonomic composition of helminths parasitizing in C. capreolus in Russia remain insufficient. Some information on the helminths of roe deer from Russia was provided in compilations by Asadov (1960), Pryadko (1976) and Govorka et al. (1988). But these data need to be complemented and clarified because of happened changes in wildlife management and fluctuations with population of C. capreolus in Russia (Danilkin, 2014). Beside that Russian zoologists (Fleurov, 1952; Heptner et al., 1961) used to consider Siberian roe deer (Capreolus pygargus Pallas, 1771) as a subspecies of European roe deer. As a result, rather extensive information on helminths of roe deer detected in Russia during XX century (Pryadko, 1976) has been presented without separation between European and Siberian roe deers. Nowadays there was noted that populations of $C$. capreolus and C. pygargus overlap in European Russia (Zvychaynaya et al., 2011). Therefore, the data on helminths parasitizing C. capreolus and C. pygargus require the re-evaluation and subdivision. Some new information concerning the helminths of Siberian roe deer was obtained during study conducted in Russian Far East (Kuznetsov et al., 2014). In this context a similar study of European roe deer is useful for understanding the differences between the helminth faunas of these ruminants. Our study focused on gastrointestinal nematodes as these helminths are characterized with substantial taxonomic diversity. In addition, gastrointestinal nematodes are admitted as a group of big significance because of high rates of infection (Aguirre et al., 1999; Hoberg et al., 2001).

\section{Material and methods}

\section{Sample collection}

Nematodes were collected from 18 European roe deer in three regions of European Russia. The sampling was made in Tver' $\left(56^{\circ} 32^{\prime} \mathrm{N}\right.$; $\left.36^{\circ} 35^{\prime} \mathrm{E}\right)$, Ryazan'
(54 $20^{\prime} \mathrm{N}$; 40 $\left.50^{\prime} \mathrm{E}\right)$ and Voronezh (51 ${ }^{\circ} 51^{\prime} \mathrm{N}$; 39 $\left.39^{\circ} 40^{\prime} \mathrm{E}\right)$ regions (Fig. 1). Some of the roe deer were shot licensed hunting, other were killed in road accidents or died from natural reasons. Species identification of the roe deer was conducted using morphological traits (Danilkin, 2014). Age of the animals was estimated based on teeth condition (Hoye, 2006). The roe deer were necropsied according to the method of partial helminthological dissection (Ivashkin et al., 1971). In each roe deer there were separately examined an abomasum, small and large intestine. These parts of the gastrointestinal tract were ligated at the level of pylorus, ileocecal junction and the rectum and then cut from each other. Then these parts of the gastrointestinal tract were opened and their contents together with washings of mucosa were placed into buckets. Then these matrixes were mixed with tap water (one part of matrix and 5-10 parts of water). When the precipitate has settled the supernatant was decanted. Then the precipitate was washed repeatedly with tap water until the supernatant become transparent. Finally the washed precipitate was conserved with $96 \%$ ethanol and then examined in the laboratory by small portions using binocular loupe. The precipitates have been examined in full volume. Detected nematodes were placed in vials with $96 \%$ ethanol. Beside this, we conducted the species identification of gastrointestinal nematodes from storage of Voronezh State Nature Reserve (the samples from four European roe deer collected in 1980s).

\section{Taxonomical identification}

In most cases an identification of detected nematodes was based on male's morphology due to big similarity of the females. The nematodes were prepared as temporary whole mounts, cleared in glycerol solution (two parts of glycerol and eight parts of water) and then examined using light microscopy at magnification of 40 to 400 . The species identification was carried out basing on morphological features presented in literature (Skrjabin et al., 1954; Ivashkin et al., 1989; Drozdz et al., 1995). The main morphological features used for the identification of gastrointestinal strongyles were the peculiarities of male reproductive system, in particular, the shape of spicules and dorsal ray. Trichuris nematodes were identified according to Ivashkin et al. (1989), Callejon et al. (2015) and Yevstafieva et al. (2018).

\section{Molecular analysis}

Several nematode specimens collected during the present study were used in molecular analysis. The DNA 


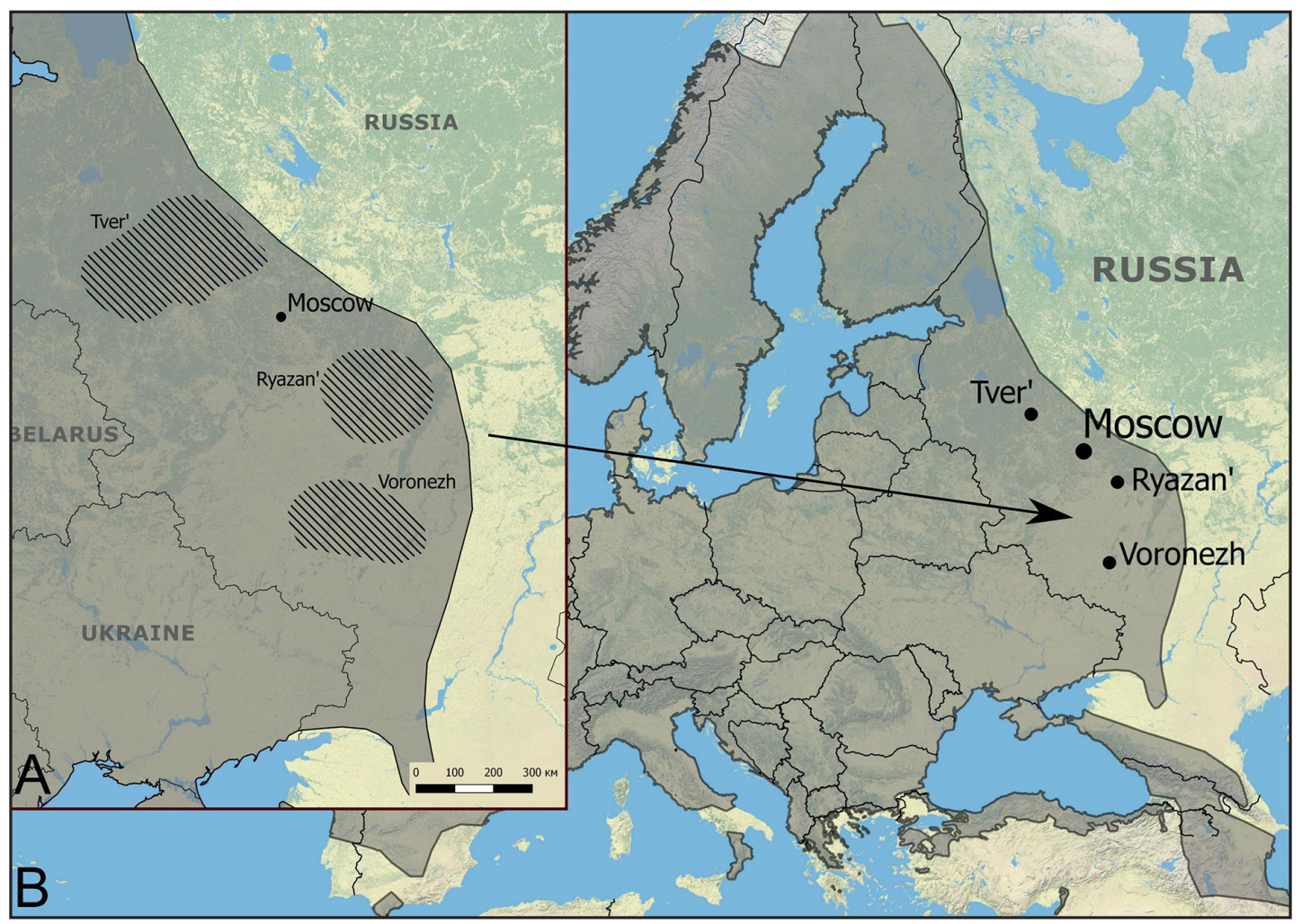

Fig. 1. The area of collection of C. capreolus nematodes (hatching) (A) within the distribution range of C. capreolus in Europe (B). The distribution range of C. capreolus in Europe is given according to IUCN (Lovari et al., 2016).

study appeared successful for two males of Ashworthius sidemi and two males of Spiculopteragia spiculoptera, collected in Voronezh region and previously identified by morphological features. Genomic DNA was isolated from single specimens of nematodes using the procedure as described by Holterman et al. (2006). In all cases, DNA was extracted from individual specimens of the nematodes.

Polymerase chain reaction (PCR) was performed to obtain the ITS-domain of rDNA using a forward primer 18SF3 (5'-GAGAGGACTGCGGACTGCTGTATCG-3'), proposed by Yamada et al. (2012) and a reverse primer NC2 (5'-TTAGTTTCT TTTCCTCCGCT-3'), proposed by Gasser et al. (1993). The PCR was performed using Sileks-M DNA amplification kit (Sileks-M, Russia) in a $25 \mu \mathrm{l}$ reaction volume according to the manufacturer's protocol. The PCR cycling conditions consisted of an initial denaturation at $95^{\circ} \mathrm{C}$ for $5 \mathrm{~min}$, followed by 40 cycles $\left(95^{\circ} \mathrm{C}\right.$ for $30 \mathrm{~s}, 50^{\circ} \mathrm{C}$ for $30 \mathrm{~s}, 72^{\circ} \mathrm{C}$ for $50 \mathrm{~s}$ ) with a final extension at $72^{\circ} \mathrm{C}$ for $10 \mathrm{~min}$. PCR products were visualised in agarose gel and then purified for sequencing using a Wizard SV Gel and PCR Clean-Up System (Promega, USA) according to the manufacturer's protocol. Obtained PCR-products were sequenced using ABI PRISMBig Dye Terminator v.3.1 kit (Applied Biosystems, USA) with an analysis of the reaction products using automatic sequencer Applied Biosystems 3730 DNA Analyzer. Obtained sequences were compared with the NCBI GenBank nucleotide database using the BLASTn 2.8.1+ program (Morgulis et al., 2008). Obtained sequences were deposited in GenBank (accession numbers are MT322612 and MT322613 for A. sidemi; MT322614 and MT322615 for S. spiculoptera).

\section{Results}

All studied individuals of $C$. capreolus appeared to be infected with nematodes. Rates of infection intensity and list of detected species are presented in Tab. 1. The species of nematodes are listed in alphabetical order. In total 15 species of gastrointestinal nematodes were found in the present study. Among them 11 species from the family Trichostrongylidae: Mazamastrongylus dagestanica (Altaev, 1953); Ostertagia antipini Matschulsky, 1950; Ostertagia leptospicularis Assadov, 1953; Ostertagia ostertagi (Stiles, 1892); Spiculopteragia asymmetrica (Ware, 1925); Spiculopteragia spiculoptera (Guschanskaja, 1931); Teladorsagia circumcincta (Stadelman, 1894); Trichostrongylus axei (Cobbold, 1879); Trichostrongylus colubriformis (Giles, 1892); Trichostrongylus vitrinus Looss, 1905 and Ashworthius sidemi Schulz, 1933. For two of the aforementioned species ( $S$. asymmetrica and $O$. antipini) their minor morphs ("S. quadrispiculata" and "O. lyrataeformis" respectively) were also detected. Besides that, there 
Table 1. The intensity of infection with gastrointestinal nematodes in studied individuals of Capreolus capreolus and the list of detected species. A - abomasum, SI — small intestine, LI — large intestine; major and minor morphs are listed via slash.

\begin{tabular}{|c|c|c|c|c|c|c|c|}
\hline \multirow{2}{*}{$\begin{array}{l}\text { Sequence } \\
\text { number } \\
\text { of the } \\
\text { studied } \\
\text { European } \\
\text { roe deer }\end{array}$} & \multirow{2}{*}{$\begin{array}{c}\text { Region } \\
\text { of sampling }\end{array}$} & \multirow{2}{*}{$\begin{array}{l}\text { Month } \\
\text { and year of } \\
\text { sampling }\end{array}$} & \multirow{2}{*}{$\begin{array}{l}\text { Sex } \\
\text { and age } \\
\text { of hosts }\end{array}$} & \multicolumn{3}{|c|}{$\begin{array}{c}\text { Number of detected } \\
\text { nematodes }\end{array}$} & \multirow{2}{*}{$\begin{array}{l}\text { Species of detected nematodes, } \\
\text { localization and number of males } \\
\text { (in brackets) }\end{array}$} \\
\hline & & & & Total & Males & Females & \\
\hline 1 & Ryazan’ & $\begin{array}{l}\text { November } \\
2013\end{array}$ & $\begin{array}{l}\text { male, } \\
2 \text { years }\end{array}$ & 71 & 31 & 40 & $\begin{array}{l}\text { Bunostomum trigonocephalum (SI-2), } \\
\text { Chabertia ovina (LI-1), Mazamastron- } \\
\text { gylus dagestanica (A-24), Nematodirus } \\
\text { filicollis (A-1, SI-3) }\end{array}$ \\
\hline 2 & Ryazan' & January 2014 & $\begin{array}{l}\text { male, } \\
4 \text { years }\end{array}$ & 57 & 22 & 35 & $\begin{array}{l}\text { B. trigonocephalum (SI-3), Ch. ovina } \\
\text { (LI-2), M. dagestanica (A-12), } \\
\text { N. filicollis (A-2, SI-3) }\end{array}$ \\
\hline 3 & Ryazan' & January 2019 & $\begin{array}{l}\text { male, } \\
6 \text { years }\end{array}$ & 1667 & 795 & 872 & $\begin{array}{l}\text { B. trigonocephalum (SI-7), Ch. ovina } \\
\text { (LI-11), N. filicollis (A-5, SI-33), } \\
\text { Ostertagia ostertagi (A-7), Teladorsagia } \\
\text { circumcincta (A-21), Trichostrongylus } \\
\text { axei (A-290, SI-27), Trichostrongylus } \\
\text { colubriformis (A-205, SI-79), Trichos- } \\
\text { trongylus vitrinus (A-99, SI-11) }\end{array}$ \\
\hline 4 & Tver' & October 2016 & $\begin{array}{l}\text { male, } 1 \\
\text { year }\end{array}$ & 491 & 211 & 280 & $\begin{array}{l}\text { Ashworthius sidemi (A-7), B. trigonoceph- } \\
\text { alum (SI-2), Ch. ovina (LI-1), N. filicollis } \\
\text { (A-3, SI-10), Ostertagia antipini (A-28), } \\
\text { Ostertagia leptospicularis (A-130), } \\
\text { Spiculopteragia asymmetrica (A-30) }\end{array}$ \\
\hline 5 & Voronezh & March 1985 & $\begin{array}{l}\text { male, } \\
\text { years }\end{array}$ & 392 & 178 & 214 & $\begin{array}{l}\text { B. trigonocephalum (SI-10), M. dages- } \\
\text { tanica (A-12), N. filicollis (SI-5), } \\
\text { O. antipini (A-19), O. leptospicularis } \\
\text { (A-113), S. asymmetrica (A-18)/ } \\
\text { "S. quadrispiculata" (A-1) }\end{array}$ \\
\hline 6 & Voronezh & April 1987 & $\begin{array}{l}\text { male, } \\
3 \text { years }\end{array}$ & 510 & 208 & 302 & $\begin{array}{l}\text { B. trigonocephalum (SI -20), M. dages- } \\
\text { tanica (A-16), N. filicollis (SI-7), } \\
\text { O. antipini (A-8), O. leptospicularis } \\
\text { (A-56), S. asymmetrica (A-81)/ } \\
\text { "S. quadrispiculata" (A-20) }\end{array}$ \\
\hline 7 & Voronezh & April 1987 & $\begin{array}{l}\text { male, } \\
4 \text { years }\end{array}$ & 1541 & 519 & 1022 & $\begin{array}{l}\text { B. trigonocephalum (SI -1), M. dages- } \\
\text { tanica (A-12), N. filicollis (A-18, SI-266), } \\
\text { O. antipini (A-129), O. leptospicularis } \\
\text { (A-44), S. asymmetrica (A-38)/ } \\
\text { "S. quadrispiculata" (A-11), Trichuris } \\
\text { globulosa (LI-1) }\end{array}$ \\
\hline 8 & Voronezh & $\begin{array}{l}\text { December } \\
1989\end{array}$ & $\begin{array}{l}\text { female, } \\
1 \text { year }\end{array}$ & 165 & 53 & 112 & $\begin{array}{l}\text { B. trigonocephalum (SI-1), M. dagestani- } \\
\text { ca (A-10), N. filicollis (SI-2), O. antipini } \\
\text { (A-9), O. leptospicularis (24), S. asym- } \\
\text { metrica (6) / "S. quadrispiculata" (1) }\end{array}$ \\
\hline 9 & Voronezh & $\begin{array}{l}\text { February } \\
2017\end{array}$ & $\begin{array}{l}\text { female, } \\
3 \text { years }\end{array}$ & 143 & 60 & 83 & $\begin{array}{l}\text { M. dagestanica (A-1), N. filicollis (A-6, } \\
\text { SI-11), O. antipini (A-34), O. lepto- } \\
\text { spicularis (A-5), S. asymmetrica (A-2), } \\
\text { Spiculopteragia spiculoptera (A-1) }\end{array}$ \\
\hline 10 & Voronezh & $\begin{array}{l}\text { February } \\
2017\end{array}$ & $\begin{array}{l}\text { male, } \\
2 \text { years }\end{array}$ & 159 & 71 & 88 & $\begin{array}{l}\text { A. sidemi (A-7), M. dagestanica (A-1), } \\
\text { N. filicollis (A-4, SI-11), O. antipini } \\
\text { (A-32)/ “O. lyrataeformis" (A-3), } \\
\text { S. asymmetrica (A-8), S. spiculoptera (A-5) }\end{array}$ \\
\hline 11 & Voronezh & January 2017 & $\begin{array}{l}\text { male, } \\
2 \text { years }\end{array}$ & 233 & 94 & 139 & $\begin{array}{l}\text { A. sidemi (A-28), M. dagestanica (A-1), } \\
\text { N. filicollis (A-4, SI-14), O. antipini } \\
\text { (A-13), O. leptospicularis (A-3), S. asym- } \\
\text { metrica (A-30) / "S. quadrispiculata" (A-1) }\end{array}$ \\
\hline 12 & Voronezh & January 2018 & $\begin{array}{l}\text { male, } \\
4 \text { years }\end{array}$ & 156 & 54 & 102 & $\begin{array}{l}\text { A. sidemi (A-10), B. trigonocephalum } \\
\text { (SI-1), N. filicollis (A-4, SI-37), } \\
\text { O. antipini (A-1), T. globulosa (LI-1) }\end{array}$ \\
\hline
\end{tabular}


Table 1 (continued)

\begin{tabular}{|c|c|c|c|c|c|c|c|}
\hline \multirow{2}{*}{$\begin{array}{l}\text { Sequence } \\
\text { number } \\
\text { of the } \\
\text { studied } \\
\text { European } \\
\text { roe deer }\end{array}$} & \multirow{2}{*}{$\begin{array}{l}\text { Region } \\
\text { of sampling }\end{array}$} & \multirow{2}{*}{$\begin{array}{l}\text { Month } \\
\text { and year of } \\
\text { sampling }\end{array}$} & \multirow{2}{*}{$\begin{array}{l}\text { Sex } \\
\text { and age } \\
\text { of hosts }\end{array}$} & \multicolumn{3}{|c|}{$\begin{array}{l}\text { Number of detected } \\
\text { nematodes }\end{array}$} & \multirow{2}{*}{$\begin{array}{l}\text { Species of detected nematodes, } \\
\text { localization and number of males } \\
\text { (in brackets) }\end{array}$} \\
\hline & & & & Total & Males & Females & \\
\hline 13 & Voronezh & $\begin{array}{l}\text { February } \\
2018\end{array}$ & $\begin{array}{l}\text { male, } \\
3 \text { years }\end{array}$ & 387 & 157 & 230 & $\begin{array}{l}\text { A. sidemi (A-39), N. filicollis (A-2, } \\
\text { SI-17), O. antipini (A-3), O. leptospicularis } \\
\text { (A-3), S. asymmetrica (A-10), T. colubri- } \\
\text { formis (A-70, SI-12), T. globulosa (LI-1) }\end{array}$ \\
\hline 14 & Voronezh & March 2018 & $\begin{array}{l}\text { male, } \\
1 \text { year }\end{array}$ & 4896 & 2078 & 2818 & $\begin{array}{l}\text { A. sidemi (A-243), N. filicollis (A-65, } \\
\text { SI-1710), O. antipini (A-5), O. lepto- } \\
\text { spicularis (A-3), T. colubriformis } \\
\text { (A-32, SI-10), T. globulosa (LI-10) }\end{array}$ \\
\hline 15 & Voronezh & March 2018 & $\begin{array}{l}\text { female, } \\
2 \text { years }\end{array}$ & 864 & 210 & 654 & $\begin{array}{l}\text { N. filicollis (A-18, SI-138), O. antipini } \\
\text { (A-30), O. leptospicularis (A-16), } \\
\text { T. globulosa (LI-8) }\end{array}$ \\
\hline 16 & Voronezh & March 2018 & $\begin{array}{l}\text { male, } \\
4 \text { years }\end{array}$ & 210 & 49 & 161 & $\begin{array}{l}\text { A. sidemi (A-2), N. filicollis (A-6, SI-17), } \\
\text { O. antipini (A-15), O. leptospicularis } \\
\text { (A-5), T. globulosa (LI-4) }\end{array}$ \\
\hline 17 & Voronezh & April 2018 & $\begin{array}{l}\text { female, } \\
3 \text { years }\end{array}$ & 95 & 33 & 62 & $\begin{array}{l}\text { A. sidemi (A-2), N. filicollis (A-3, SI-11), } \\
\text { O. antipini (A-14), O. leptospicularis } \\
\text { (A-3) }\end{array}$ \\
\hline 18 & Voronezh & April 2018 & $\begin{array}{l}\text { male, } \\
2 \text { years }\end{array}$ & 2578 & 602 & 1976 & $\begin{array}{l}\text { A. sidemi (A-501), N. filicollis (A-19, } \\
\text { SI-65), O. antipini (A-10), O. leptospicu- } \\
\text { laris (A-4), T. globulosa (LI-3) }\end{array}$ \\
\hline
\end{tabular}

were detected Bunostomum trigonocephalum (Rudolphi, 1808) (family Ancylostomatidae); Chabertia ovina (Fabricius, 1794) (Chabertiidae); Nematodirus filicollis (Rudolphi, 1802) (Molineidae) and Trichuris globulosa (Linstow, 1901) (Trichuridae).

For two of the detected species they taxonomic affiliation was confirmed by molecular analysis. Obtained sequences of $A$. sidemi (790 bp long contained partial 18S, complete ITS1 and 5.8S and partial ITS2 rDNA) and S. spiculoptera (908 bp long contained partial $18 \mathrm{~S}$, complete ITS1 and 5.8S and partial ITS2 rDNA) were compared with the GenBank nucleotide database using the BLAST. The sequences of $A$. sidemi showed $99.75 \%$ identity to $A$. sidem $i$ sequence (accession number EF 467325.1) and sequences of $S$. spiculoptera showed $98.65 \%$ identity to $S$. spiculoptera sequence (accession number KP 984759.1). Additionally, before using in molecular analysis, the specimens of $S$. spiculoptera were differentiated from the morphologically close Spiculopteragia houdemeri. The last one species has spicules joined at the end (Drozdz, 1965), whereas S. spiculoptera has separated spicules.

\section{Discussion}

Most of the studied individuals of $C$. capreolus showed rather big species diversity of nematodes (Tab. 1). The maximum number of the nematode species registered in one individual was eight, minimum number was four and mean was 5.7. The similar level of the diversity was noted in previous studies of C. capreolus conducted in various European countries (Dunn, 1965; Bernard et al., 1988; Borgsteede et al., 1990; Drozdz et al., 1992; Aguirre et al., 1999; Cisek et al., 2003; Kuzmina et al., 2010; Pato et al., 2013; Demiaszkiewicz et al., 2017). We tend to explain this diversity by the peculiarities of roe deer behavior, such as abilities for long-distance movements and co-pasturing with other ruminants (Danilkin, 2014). The intensity of infection varied from rather low numbers, such as 57 specimens of all detected species (in four-year age male from Ryazan') to significant burden with 4896 specimens (in one-year age male from Voronezh).

Nematodirus filicollis (Rudolphi, 1802) showed the highest rates of the intensity and extensity of infection in the present study (Tabs. 1,2). Similar data were obtained during studies of C. capreolus in Britain (Dunn, 1965), Belgium (Bernard et al., 1988), Spain (Pato et al., 2013) and Turkey (Bolukbas et al., 2012). It worth to mention, that Khrustalev (2009) has revealed, based on revision of Nematodirus spp. from Russia, that $N$. filicollis is a typical parasite for roe deer, while in other hosts it was often reported erroneously.

The high prevalence has been detected as well for Ostertagia antipini Matschulski, 1950 and Ostertagia leptospicularis Assadov, 1953 (Tab. 2). The last one is widespread among wild and domestic ruminants in 
Table 2. The extensity of infection with gastrointestinal nematodes in studied individuals $(n=18)$ of Capreolus capreolus.

\begin{tabular}{|l|c|c|c|}
\hline \multicolumn{1}{|c|}{ Nematode species } & Regions of detection & $\begin{array}{c}\text { The number of infected } \\
\text { animals }\end{array}$ & Extensity of infection (\%) \\
\hline Ashworthius sidemi & Tver', Voronezh & 9 & 50.0 \\
\hline Bunostomum trigonocephalum & Ryazan', Tver', Voronezh & 9 & 50.0 \\
\hline Chabertia ovina & Ryazan', Tver' & 4 & 22.2 \\
\hline Mazamastrongylus dagestanica & Ryazan', Voronezh & 9 & 50.0 \\
\hline Nematodirus filicollis & Ryazan', Tver', Voronezh & 18 & 100.0 \\
\hline Ostertagia antipini & Tver', Voronezh & 15 & 83.3 \\
\hline Ostertagia leptospicularis & Tver', Voronezh & 13 & 72.2 \\
\hline Ostertagia ostertagi & Ryazan' & 1 & 5.6 \\
\hline Spiculopteragia asymmetrica & Tver', Voronezh & 9 & 50.0 \\
\hline Spiculopteragia spiculoptera & Voronezh & 2 & 11.1 \\
\hline Teladorsagia circumcincta & Ryazan' & 1 & 5.6 \\
\hline Trichostrongylus axei & Ryazan' & 1 & 5.6 \\
\hline Trichostrongylus colubriformis & Ryazan', Voronezh & 3 & 16.7 \\
\hline Trichostrongylus vitrinus & Ryazan' & 7 & 5.6 \\
\hline Trichuris globulosa & Voronezh & & 38.9 \\
\hline
\end{tabular}

Europe (Wyrobisz-Papiewska et al., 2018). In contrast with that, the data on occurrence of $O$. antipini limited with small number of countries and host species (Govorka et al., 1988; Kuznetsov et al., 2014; WyrobiszPapiewska et al., 2018). We believe that specimens of $O$. antipini and $O$. leptospicularis in some cases cannot be accurately differentiated from each other due to big morphological similarity. We agree with WyrobiszPapiewska et al. (2018), that O. leptospicularis may represent a potential species complex.

Spiculopteragia asymmetrica (Ware, 1925) was found in nine of the studied roe deer from Tver' and Voronezh regions (Tab. 2). In five cases the minor morphs of this species ("S. quadrispiculata") were also detected. A small number of specimens of Spiculopteragia spiculoptera (Guschanskaja, 1931) were found in two roe deer from Voronezh, in both cases together with $S$. asymmetrica (Tabs. 1, 2). The males of these two species could be easily differentiated from each other basing on morphology of distal parts of the spicules, therefore this detection is not on doubt. Thus, we note a possibility of simultaneous parasitizing of $S$. asymmetrica and S. spiculoptera. Zaffaroni et al. (2000) consider $S$. spiculoptera along with $O$. leptospicularis as a dominant species in Cervids. A survey by Rossi et al. (1997) also showed that S. spiculoptera and O. leptospicularis were the dominant abomasal species of European roe deer. Similar results have been got by Dunn (1965), Bernard et al. (1988), Bolukbas et al. (2012) and Pato et al. (2013). Our data confirm the high importance of $O$. leptospicularis, but the levels of prevalence and abundance of S. spiculoptera were low. On the other hand, we noted quite high prevalence of $S$. asymmetrica registered in two regions (Tver' and Voronezh). In European roe deer S. asymmetrica was previously registered in Britain (Dunn, 1965), Belgium (Bernard et al., 1988) and Spain (Morrondo et al., 2010).
Mazamastrongylus dagestanica (Altaev, 1952) was detected in $50 \%$ of the studied roe deer from two regions (Tab. 2). At the same time, the intensity of infection with $M$. dagestanica was rather low (Tab. 1). Apparently, roe deer were infected with $M$. dagestanica when sharing the territory with elk, which is the obligate host for this parasite (Wyrobisz-Papiewska et al., 2018). In European roe deer $M$. dagestanica was registered in Poland (Wyrobisz-Papiewska et al., 2018). Recently M. dagestanica was reported in Siberian roe deer from Russian Far East (Kuznetsov et al., 2014).

Ashworthius sidemi Schulz, 1933 was found in two studied regions (Tver' and Voronezh), the intensity of infection ranged from a few specimens to several hundred specimens and the extensity of infection was $50 \%$ (Tabs. $1,2)$. This species was found in majority of roe deer from Voronezh studied in 2017-2018, but was not found in the samples from Voronezh collected in 1980s. This fact corroborates the spreading of $A$. sidemi in Europe during last decades, noted by several studies (Drozdz et al., 2003; Hoglund et al., 2007; Vadlejch et al., 2016; Demiaszkiewicz et al., 2017).

Bunostomum trigonocephalum (Rudolphi, 1802) was found in nine of the studied roe deer in all of the explored regions (Tabs. 1,2). The number of discovered males ranged from 1 to 20 , and the number of females ranged from one to seven individuals. This species is widespread in domestic and wild ruminants all over the word, this nematode reported from European roe deer in Netherlands (Borgsteede et al., 1990), Poland (Drozdz et al., 1992) and Armenia (Movsesyan et al., 2019).

We found Trichuris globulosa (Linstow, 1901) in roe deer from Voronezh (one sample collected in 1987 and six samples collected in 2018). The number of males ranged from 1 to 10 , and the number of females ranged from one to 18 individuals. This species is widespread in domestic and wild ruminants, both in Europe and in other 
parts of the world (Govorka et al., 1988). Yevstafieva et al. (2018) reported this nematode in south-eastern regions of Ukraine neighboring with Voronezh region.

Chabertia ovina (Fabricius, 1788) noted in four roe deer from two regions (Tab. 2). The number of males of C. ovina ranged from 1 to 11 , and the number of females ranged from 2 to 15 individuals. This nematode is known to be quite common in domestic and wild ruminants. In C. capreolus this nematode reported in Sweden (Aguirre et al., 1999), Britain (Dunn, 1965), Belgium (Bernard et al., 1988), Netherlands (Borgsteede et al., 1990), Poland (Drozdz et al., (1992), Belarus (Shimalov \& Shimalov, 2003), Ukraine (Kuzmina et al., 2010), Spain (Pato et al., 2013), Turkey (Bolukbas et al., 2012), Armenia (Movsesyan et al., 2019) and Romania (Hora et al., 2017).

We found three species of the genus Trichostrongylus, in all cases with rather high intensity (Tab. 1). Trichostrongylus colubriformis (Giles, 1892) was detected in two roe deer from Voronezh and one from Ryazan' (Tabs. 1, 2). In Voronezh T. colubriformis was found only in recently collected samples, but was not found in the samples collected in 1980s. Trichostrongylus axei (Cobbold, 1879) and Trichostrongylus vitrinus (Looss, 1905) were found in one individual of C. capreolus which has been hunted near agricultural area in Ryazan' region. This individual of $C$. capreolus showed the highest species diversity (eight species of nematodes) in the present study. We tend to explain it because of contacts among C. capreolus and domestic ruminants. The detected species of Trichostrongylus are widespread among domestic and wild ruminants, and have been reported from the areas with different climatic conditions (Skrjabin et al., 1954; Govorka et al., 1988). In particular, these three species of Trichostrongylus reported from C. capreolus in Sweden (Aguirre et al., 1999), Italy (Zaffaroni et al., 2000), Spain (Pato et al., 2013), Turkey (Bolukbas et al., 2012) and Armenia (Movsesyan et al., 2019).

Ostertagia ostertagi (Stiles, 1892) as well as T. circumcincta (Stadelmann, 1894) was detected in one individual of European roe deer only (Ryazan' region). These species are more typical for Bovidae (WyrobiszPapiewska et al., 2018) and this roe deer was supposedly infected when sharing pastures with domestic ruminants. Interestingly, that Drozdz et al. (1992) in north-eastern Poland found $O$. ostertagi in roe deer in all seasons except winter, but our finding of $O$. ostertagi was made in January.

Thus, all nematode species found in the present study have already been reported from $C$. capreolus in various European countries. Most species of nematodes detected in the present study were also previously noted in other wild ruminants (such as elk and red deer) inhabiting European Russia and neighboring countries (Govorka et al., 1988). However, S. asymmetrica, as well as its minor morph ("S. quadrispiculata") was never previously found in European roe deer in Russia. Ashworthius sidemi was detected in C. capreolus in Russia for the first time by Kuznetsov et al. (2018) based on the necropsies of three roe deer conducted in 2016-2017. In the present study we supplement the data concerning $A$. sidem $i$ with results of necropsies of C. capreolus conducted in 2018, and two of the studied roe deer appeared to be infected with rather high intensity numbering several hundred specimens of A. sidemi. Four species of gastrointestinal nematodes, which we found in the present study (T. circumcincta, T. axei, T. colubriformis and T. vitrinus) are considered to be zoonotic (Skrjabin et al., 1954; Mizani et al., 2017).

Four species of gastrointestinal nematodes (N.filicollis, $O$. antipini, S. spiculoptera and $M$. dagestanica) detected in the present study were reported for Siberian roe deer as well (Kuznetsov et al., 2014). M. dagestanica showed similar infection rates both for C. capreolus and C. pygargus. S. spiculoptera was found in C. pygargus with an average of 173 specimens per animal, but in $C$. capreolus we found this nematode in low numbers. On the contrary, $N$. filicollis and $O$. antipini were found in low numbers in Siberian roe deer. In addition to the above mentioned, three other species of gastrointestinal nematodes (Oesophagostomum venulosum (Rudolphi, 1809), Pygarginema skrjabini Kadenazii, 1948 and Spiculopteragia schulzi (Rajewskaja, 1930)) were reported from Siberian roe deer (Oshmarin \& Parukhin, 1963; Kuznetsov et al., 2014). Thus, the species composition of gastrointestinal nematodes of C. pygargus appears to be less diverse and coincides with that of $C$. capreolus in four species only.

The biggest variety of nematode species we detected in an abomasum (Tab. 1). Here were found twelve species and two of these species (S. asymmetrica and O. antipini) were presented with their major and minor morphs. Four species ( $N$. filicollis, T. axei, T. colubriformis and $T$. vitrinus) were detected both in abomasa and small intestines, but the first one prevailed in small intestines whereas Trichostrongylus spp. was more abundant in abomasum.

\section{Conclusion}

The helminthological study of $C$. capreolus from Russia detected rather high species diversity of gastrointestinal nematodes. Most of the detected nematode species are common both for European roe deer and other aboriginal wild ruminants (elk, red deer) habituating this area. In some cases the helminth fauna of $C$. capreolus was added with species more typical for domestic ruminants. One of the detected species, Spiculopteragia asymmetrica (as well as its minor morph "S. quadrispiculata"), has been reported in European roe deer in Russia for the first time. The detection of Ashworthius sidemi with rather high intensity and extensity of infection confirms the trend of spreading this Asian nematode among aboriginal ruminants in Europe. The presence of zoonotic nematodes ( $T$. circumcincta, T. axei, T. colubriformis and T. vitrinus) in the helminth fauna of $C$. capreolus deserves a special attention.

ACKNOWLEDGMENTS. The authors express their gratitude to Anton Aksyonov and Alexander Khutoryanskyi for the assistance in collecting the 
samples of nematodes from European roe deer. Our gratitude also goes to the reviewers for valuable comments regarding the manuscript.

\section{References}

Aguirre A.A., Brojer C. \& Morner T. 1999. Descriptive epidemiology of roe deer mortality in Sweden // Journal Wildlife Diseases. Vol.35. No.4. P.753-762.

Asadov S.M. 1960. [Helminth fauna of ruminants in USSR and its ecological-geographical analysis]. Baku: Izdatel'stvo Akademii nauk Azerbaydzhanskoy SSR. 512 p. [in Russian].

Bernard J., Biesemans W. \& Mathy P. 1988. [Gastrointestinal parasitic nematodes of wild ungulates in Belgian Ardennes]// Schweizer Archiv für Tierheilkunde. Vol.130. P.77-103.

Bolukbas C.S., Gurler A.T., Beyhan Y.E., Acici M. \& Umur S. 2012. Helminths of roe deer (Capreolus capreolus) in the Middle Black Sea Region of Turkey // Parasitology International. Vol.61. No.4. P.729-730.

Borgsteede F.H.M., von, Jansen J., Nispen tot Pannerden H.P.M., van, Burg W.P.J., van der, Noorman N., Poutsma J. \& Kotter J.F. 1990. An investigation of the endoparasitic helminth fauna of roe deer (Capreolus capreolus L.) in the Netherlands // Zeitschrift für Jagdwissenschaft. Vol.36. P.104-109.

Callejón R., Gutiérrez-Avilés L., Halajian A., Zurita A., Rojas M. \& Cutillas C. 2015. Taxonomy and phylogeny of Trichuris globulosa Von Linstow, 1901 from camels. A review of Trichuris species parasitizing herbivorous // Infection, Genetics and Evolution. Vol.34. P.61-74.

Cisek A., Balicka-Ramisz A., Ramisz A. \& Pilarczyk B. 2003. Occurrence of gastro-intestinal nematodes in cervids (Cervidae) of North-Western Poland // Electronic Journal Polish Agricultural University. Vol.6. No.2.

Danilkin A.A. 2014. [Roe Deer (Biological Bases of Resource Management)]. Moscow: KMK Scientific Press 338 p. [in Russian, with English summary].

Demiaszkiewicz A.W., Merta D., Kobielski J., Filip K.J. \& Pyziel A.M. 2017. Expansion of Ashworthius sidemi in red deer and roe deer from the Lower Silesian Wilderness and its impact on infection with other gastrointestinal nematodes // Acta Parasitologica. Vol.62. No.4. P.853-857.

Drozdz J. 1965. Studies on helminths and helminthiases in Cervidae. I. Revision of the subfamily Ostertagiinae Sarwar, 1956 and an attempt to explain the phylogenesis of its representatives // Acta Parasitologica Polonica. Vol.13. No.44. P.445-481.

Drozdz J. 1995. Polymorphism in the Ostertagiinae LopezNeyra, 1947 and comments on the systematics of these nematodes // Systematic Parasitology. Vol.32. P.91-99.

Drozdz J., Demiaszkiewicz A.W. \& Lachowicz J. 1992. The helminth fauna of roe deer Capreolus capreolus (L.) in a hunting area inhabited by red deer, elk and European bison (Borecka Forest, Poland) over the yearly cycle // Acta Parasitologica. Vol.37. No.2. P.83-88.

Drozdz J., Demiaszkiewicz A.W. \& Lachowicz J. 2003. Expansion of the Asiatic parasite Ashworthius sidemi (Nematoda, Trichostrongylidae) in wild ruminants in Polish territory // Parasitology Research. Vol.89. No.2. P.94-97.
Dunn A.M. 1965. The gastro-intestinal helminths of wild ruminants in Britain. I. Roe deer, Capreolus capreolus capreolus // Parasitology. Vol.55. P.739-745.

Fleurov K.K. 1952. [Fauna of USSR. Mammals. Vol 1, Is 2. Musk deer and deer]. Moscow-Leningrad: Izdatel'stvo Akademii nauk SSSR. 256 p. [in Russian].

Gasser R.B., Chilton N.B., Hoste H. \& Beveridge I. 1993. Rapid sequencing of rDNA from single worms and eggs of parasitic helminths // Nucleic Acids Research. Vol.89. P.2525-2526.

Govorka I., Maklakova L.P., Mitukh I., Pelgunov A.N., Rykovskii A.S., Semenova M.K., Sonin M.D., ErkhardovaKotrla B. \& Iurashek V. 1988. [Helminths of Wild Ungulates of Eastern Europe]. Moscow: Nauka. 208 p. [in Russian].

Grubb P. 2005. Order Artiodactyla // Wilson D.E. \& Reeder D.M. (eds.). Mammal Species of the World. A Taxonomic and Geographic Reference. 3rd edn. Vol.1. Baltimore: Johns Hopkins University Press. P.637-722.

Heptner V.G., Nasimovich A.A. \& Bannikov A.G. 1961. [Mammals of the Soviet Union. Vol.1. Cloven-hoofed and Odd-toed Animals]. Moscow: Vysshaya Shkola. 776 p. [in Russian].

Hoberg E.P., Kocan A.A. \& Rickard L.G. 2001. Gastrointestinal strongyles in wild ruminants // Samuel W., Pubis M. \& Kocan A.A. (eds.). Parasitic Diseases of Wild Mammals. Ames: Iowa State University Press. P.193-227.

Hoglund J., Christensson D., Holmdahl J., Morner T., Osterman E. \& Uhlhorn H. 2007. The first record of the nematode Ashworthius sidemi in Sweden // Proceedings of 21st International Conference of WAAVP. Ghent, Belgium. P.276.

Holterman M., Wurff A., Elsen S., Megen H., Bongers T., Holovachov A., Bakker J. \& Helder J. 2006. Phylumwide analysis of SSU rDNA reveals deep phylogenetic relationships among nematodes and accelerated evolution towards crown clades // Molecular Biology and Evolution. Vol.23. P.1792-1800.

Hora F.S., Genchi C., Ferrari N., Morariu S., Mederle N. \& Dărăbus G. 2017. Frequency of gastrointestinal and pulmonary helminth infections in wild deer from western Romania // Veterinary Parasitology: Regional Studies and Reports. Vol.8. P.75-77.

Hoye T.T. 2006. Age determination in roe deer: a new approach to tooth wear evaluated on known age in individuals // Acta Theriologica. Vol.51. No.2. P.205-214.

Irvine R.J., Corbishley H., Pilkington J.G. \& Albon S.D. 2006. Low-level parasitic worm burdens may reduce body condition in free-ranging red deer (Cervus elaphus) // Parasitology. Vol.133. No.4. P.465-475.

Ivashkin V.M., Kontrimavichus V.I. \& Nazarova N.S. 1971. [Methods of Terrestrial Mammals' Helminths Collection and Study]. Moscow: Nauka. 124 p. [in Russian].

Ivashkin V.M., Orypov A.O. \& Sonin M.D. 1989. [Keys to the Helminths of Small Cattle]. Moscow: Nauka. 255 p. [in Russian].

Khrustalev A.V. 2009. [Nematodirus filicollis in Russia. Blanket distribution or mistakes of identification?] // Teoriya i praktika bor'by s parazitarnymi boleznyami. Vol.10. P.409-412 [in Russian, with English summary].

Kuzmina T.A., Kharchenko V.A. \& Malega A.M. 2010. Helminth fauna of roe deer (Capreolus capreolus) in 
Ukraine: biodiversity and parasite community // Vestnik Zoologii. Vol.44. No.1. P.15-22.

Kuznetsov D.N., Seryodkin I.V., Maksimova D.A. \& Khrustalev A.V. 2014. Helminth fauna of the Siberian roe (Capreolus pygargus) digestive tract // Achievements in the Life Sciences. Vol.8. No.2. P.121-122.

Kuznetsov D., Romashova N. \& Romashov B. 2018. The first detection of Ashworthius sidemi (Nematoda, Trichostrongylidae) in roe deer (Capreolus capreolus) in Russia // Veterinary Parasitology: Regional Studies and Reports. Vol.14. P.200-203.

Lovari S., Herrero J., Masseti M., Ambarli H., Lorenzini R. \& Giannatos G. 2016. Capreolus capreolus. The IUCN Red List of Threatened Species 2016: e.T42395A22161386.

Mizani A., Gill P., Daryani A., Sarvi S., Amouei A., Katrimi A.B., Soleymani E., Mirshafiee S., Gholami S., Hosseini S.A., Gholami S., Rahimi M.T., Hashemi-Soteh M.B. \& SharifM. 2017. A multiplex restriction enzyme-PCR for unequivocal identification and differentiation of Trichostrongylus species in human samples // Acta Tropica. Vol.173. P.180-184.

Morgulis A., Coulouris G., Raytselis Y., Madden T., Agarwala R. \& Schaffer A. 2008. Database indexing for production MegaBLAST searches // Bioinformatics. Vol.24. P.1757-1764.

Morrondo P., Vázquez L. \& Diez-Baños P. 2010. Parasitic infections of wild ruminants in Spain with special attention to roe deer and chamois // Parassitologia. Vol.52. No.1-2. P.155-158.

Movsesyan S.O., Nikoghosian M.A., Petrosian R.A., Voronin M.V. \& Kuznetsov D.N. 2019. Species diversity of nematodes in domestic and wild ruminants of Armenia // Annals of Parasitology. Vol.65. No.2. P.113-120.

Oshmarin P.G. \& Parukhin A.M. 1963. [Trematodes and nematodes of birds and mammals of the Sikhote-Alin Reserve] // Trudy Sikhote-Alinskogo Zapovednika. Vol.3. P.121-181 [in Russian].

Osinska B., Demiaszkiewicz A. \& Lachowicz J. 2010 Pathological lesions in European bison (Bison bonasus) with infestation by Ashworthius sidemi (Nematoda, Trichostrongylidae) // Polish Journal of Veterinary Sciences. Vol.13. No.1. P.63-67.

Pato F.J., Vázquez L., Diez-Baños N., López C., SánchezAndrade R., Fernández G., Diez-Baños P., Panadero R., Diaz P. \& Morrondo P. 2013. Gastrointestinal nematode infections in roe deer (Capreolus capreolus) from the NW of the Iberian Peninsula: assessment of some risk factors // Veterinary Parasitology. Vol.196. No.1-2. P.136-142.

Pryadko E.I. 1976. [Helminths of Deer]. Alma-Ata: Nauka. 224 p. [in Russian].
Skrjabin K.I., Shikhobalova N.P. \& Shults R.S. 1954. [Essentials of Nematodology. Vol.3. Trichostrongylids of Animals and Man]. Moscow: Izdatel'stvo Akademii nauk SSSR. 683 p. [in Russian].

Rossi L., Eckel B. \& Ferroglio E. 1997. A survey of the gastro-intestinal nematodes of roe deer (Capreolus capreolus) in a mountain habitat // Parassitologia. Vol.39. No.4. P.303-312.

Stien A., Irvine R., Ropstad E., Halvorsen O., Langvatn R. \& Albon S. 2002. The impact of gastrointestinal nematodes on wild reindeer: experimental and cross-sectional studies // Journal of Animal Ecology. Vol.71. No.6. P.937-945.

Shimalov V.V. \& Shimalov V.T. 2003. Helminth fauna of cervids in Belorussian Polesie // Parasitology Research. Vol.89. P.75-76.

Vadlejch J., Kyrianova I., Rylkova K., Zikmund M. \& Langrova I. 2016. Health risks associated with wild animal translocation: a case of the European bison and an alien parasite // Biological Invasions. Vol.19. P.1121-1125.

Wyrobisz-Papiewska A., Kowal J., Nosal P., Chovancová G. \& Rehbein S. 2018. Host specificity and species diversity of the Ostertagiinae Lopez-Neyra, 1947 in ruminants: a European perspective // Parasites \& Vectors. Vol.11. No.369.

Yamada S., Yoshida A., Yoshida K., Kuraishi T., Hattori S., Kai C., Nagai Y., Sakoda T., Tatara M., Abe S. \& Fukumoto S. 2012. Phylogenetic relationships of three species within the family Heligmonellidae (Nematoda; Heligmosomoidea) from Japanese rodents and a lagomorph based on the sequences of ribosomal DNA internal transcribed spacers, ITS-1 and ITS-2 // Japanese Journal of Veterinary Research. Vol.60. No.1. P.15-21.

Yevstafieva V.A., Yuskiv I.D., Melnychuk V.V., Yasnolob I.O., Kovalenko V.A. \& Horb K.O. 2018. Nematodes of the genus Trichuris (Nematoda, Trichuridae), parasitizing sheep in Central and South-Eastern regions of Ukraine // Vestnik Zoologii. Vol.52. No.3. P.193-204.

Zaffaroni E., Manfredi M.T., Citterio C., Sala M., Piccolo G. \& Lanfranchi P. 2000. Host specificity of abomasal nematodes in free ranging alpine ruminants // Veterinary Parasitology. Vol.90. P.221-230.

Zvychaynaya E.Y., Kiryakulov V.M., Kholodova M.V. \& Danilkin A.A. 2011. [Roe deer (Capreolus) from Moscow Area: analysis of mitochondrial control region polymorphism] // Vestnik Okhotovedeniya. Vol.8. No.2. P.168-172 [in Russian, with English summary]. 